Wayne State University

DigitalCommons@WayneState

Communication Faculty Research Publications

Communication

8-1-2005

\title{
The African Telecommunications Union: A Pan- African Approach to Telecommunications Reform
}

Patricia K. McCormick

Wayne State University, dz7089@wayne.edu

\section{Recommended Citation}

McCormick, Patricia K. "The African telecommunications union: a Pan-African approach to telecommunications reform."

Telecommunications Policy 29.7 (2005): 467-572.

Available at: http://digitalcommons.wayne.edu/commfrp/2

This Article is brought to you for free and open access by the Communication at DigitalCommons@WayneState. It has been accepted for inclusion in Communication Faculty Research Publications by an authorized administrator of DigitalCommons@WayneState. 
NOTICE IN COMPLIANCE WITH PUBLISHER POLICY: This is the author's final manuscript version, post-peer-review, of a work accepted for publication in Telecommunications Policy. Changes resulting from the publishing process, such as further peer review, editing, corrections, structural formatting, and other quality control mechanisms may not be reflected in this document. Changes may have been made to this work since it was submitted for publication. This version has been formatted for archiving; a definitive version was subsequently published in Telecommunications Policy, 29(7). August 2005. pp. 467-572. Available online at: http://dx.doi.org/10.1016/j.telpol.2005.04.001 


\title{
The African telecommunications union: A Pan-African approach to tele- communications reform
}

PATRICIA K. McCORMICK, Department of Radio, TV and Film, The John H. Johnson School of Communications, Howard University, 525 Bryant Street, NW, Washington, DC 20059, USA

\begin{abstract}
This article examines the organisational structure and strategic plans of the African Telecommunications Union (ATU). Although the ATU has been restructured to include private telecommunications entities as associate members, it remains essentially an inter-governmental agency. The article assesses the benefits of a regional approach to telecommunications reform and proposes that regional economic organisations replace the nation states as members of the ATU. Although the goals of the ATU, as articulated in its strategic plans are laudable, clearly defined benchmarks and specific strategies to achieve them are needed to make the organisation more effective.
\end{abstract}

Keywords Africa, Telecommunications, Reform, Regulation, Policy, Regional Integration

\section{INTRODUCTION}

If the wealth and socio-economic health of a region is defined by its ability to participate in the networked economy, Africa is indeed impoverished. In an era of accelerated technological change, Africa's technological dependency and underdevelopment utterly impairs its ability to compete in the global economy. This is evidenced by it comprising less than one percent of global trade (Oshikoya \& Hussain, 1999). The African continent grows increasingly marginalized as technological advancements in other areas of the world are accompanied by new patterns of dependency in Africa. This situation is further aggravated by the policies of the predatory, neocolonial state (Castells, 2000). The capitalintensive nature of the sector, coupled with Africa's rent position in terms of technology and its consequent inability to control costs, also places unattainable demands on the continent. Africa is the most indebted region in the world in per capita terms with nearly half of its population subsisting on less than one US dollar per day (African Telecommunications Union (ATU), 2001a). As the only region of the world where poverty levels are projected to increase, Africa can illafford to invest in the expansion of telecommunication services. Although the number of telephone lines has increased in absolute terms on the continent, the growth rate needs to be much greater to have a positive impact and outpace population growth, which at around three percent is the highest in the world (Oshikoya \& Hussain, 1999).

To remedy this situation, the African Telecommunications Union (ATU) has articulated its mission to effectively promote the rapid development of information communications technologies in Africa in order to achieve universal access and full inter-country connectivity (African Telecommunications Union (ATU), 1999). The ATU is not only cognizant of the vital role the telecommunications sector plays in promoting socio-economic development, but it also recognizes the need to develop telecommunications networks and services in a concerted, planned and integrated manner (African Telecommunications Union (ATU), 1999). The potential for cooperation between states is arguably highest when the issue at stake reinforces an interdependent relationship among the states involved, so collaboration on an issue-specific area, such as telecommunications, may offer better potential for success than macro-level schemes (Akinyemi, 2001). This article thus examines the organisational structure and strategic plans of the ATU, as well as the challenges it faces in achieving its goals and objectives to facilitate telecommunications policy reform and related infrastructure and service developments in its member states. This 
article assesses the efforts of the ATU for it is important that this continental organisation, in its various endeavours, actually achieves tangible results and is not merely a Pan-African paper tiger.

\section{METHODOLOGY}

Since the research is interdisciplinary in nature with several contemporary, interrelated issues being examined, this work employs the case study, which draws upon multiple data sources to develop converging lines of inquiry or triangulation to investigate a specific phenomenon. A major strength of case study data collection is its use of several different sources of evidence. This study, based on field work conducted in Kenya in the summer of 2002, draws on three primary sources of evidence: documentation, archival records, and elite interviews. Documentation sources include, among other references, policy and legal documents from the ATU. In the process of gathering data, interviews were conducted with officials of the ATU, including the secretary general, as well as others intimately involved in the telecommunications sector. These interviews, while open-ended in nature, followed a specific set of questions concerning telecommunications policy and infrastructure developments in Africa.

\section{TELECOMMUNICATIONS IN AFRICA: AN OVERVIEW}

Africa, with a population of some 840 million, is one of the least networked or computerized regions in the world. The continent claims 12 percent of the world's population, but only 2 percent of the world's telephones, which are unevenly distributed both within and between countries. Eighty percent of the lines are concentrated in just eight countries, and in some states teledensity rates are as low as one telephone line per 1000 people (African Telecommunications Union (ATU), 2001a, p. 2). Paradoxically, although Africa encompasses thirty-four of the world's least developed countries, it boasts some of the highest costs for international calls and the laying of fixed telephone lines. It is estimated that the average cost per line in the region is over US\$4500, which is more than three times the industry average of US\$1500 (Oshikoya \& Hussain, 1999), and results in prohibitive subscription costs. Such institutional inefficiency coupled with inadequate human resources and maintenance problems that derive from an absence of common operating standards, proper maintenance procedures, and standardized equipment, together account in part for the demise of fixed line telephony in Africa.

This situation demands that African states restructure and reform the telecommunications sector and invest in mobile services in order to promote network efficiencies and extend the infrastructure to the rural populace. Despite comprising the majority of Africans, the rural population has yet to benefit from the deployment of new communication technologies, since investment in the more profitable urban and international markets has been at the expense of providing access to rural and low-income users. Developments in the telecommunications sector, including the rapid growth of pre-paid cellular phone services, have remained an urban phenomenon as service providers argue that it is not economically feasible to roll out a network to cover an entire country. The International Telecommunications Union (ITU) (2004) estimates that less than half the population in Sub-Saharan Africa was covered by a mobile signal in 2003. Although Africa's mobile market has been the fastest growing of any region over the past 5 years, raising its mobile penetration to 6.2 per 100 inhabitants at the end of 2003, twice the fixed rate, this still represents the lowest mobile penetration of any region (International Telecommunications Union (ITU), 2004). Furthermore, the fact that rural and urban telephony statistics are not disaggregated from national statistics reflects and fosters the lack of priority accorded the development of this sector in rural areas, as figures of urban growth conceal the often stagnant picture of rural telecommunications development (Shanmugavelan \& Warnock, 2004). Universal access policies and mechanisms, which ensure that profits from the lucrative sectors are used to provide service in 
rural and economically deprived areas, have not been instituted. Rural coverage requirements must be a stated requirement of license obligations and must be enforced, since African states are likely to expand the telecommunications sector through a wireless platform.

It is important to note, though, that while mobile services carry relatively lower fixed network costs than wire line networks, especially in areas of low population density, the cost of mobile-based equipment and calls generally continue to be higher than fixed-line systems, so mobile services may still be beyond the economic reach of rural people. To facilitate mobile access, a single cell phone and thus its associated costs is often shared among family members or friends. Also employed to reduce costs are beep-calls, that is when one places a call to a mobile phone owner and then ends the call before it incurs charges as a way to request the mobile phone owner to return a call or as a pre-arranged message ("I'll beep when I'm leaving") (Chango, 2004). To address this and other cost-saving practices, some companies are now providing a free 'Call Me' text message together with the owner's phone number as well as removing the time constraint to buy air-time or recharge credit on prepaid packages (Chango, 2004). It remains vitally important to employ competition and regulation to secure the economic viability of mobile services as an option to increase the telephone penetration or tele-density rate in rural areas, since, according to the International Telecommunications Union (ITU) $(2004$, p. 24), the average African expenditure of US\$27 per month for mobile services is more than half the official average African per capita income, testimony to the existing urban clientele.

Mobile service providers have also yet to invest heavily in mobile data services built over the existing GSM platform, which enables slow and medium-speed Internet access (Commonwealth Telecommunications Organisation, 2002). There are various advanced technologies emerging that offer higher-speed access to portable Internet users, but mobile operators in Africa have largely confined themselves to the voice market because they are uncertain of the financial viability of mobile data, since much of the information on the Internet is irrelevant to the needs of the people in rural African communities and the commercial character of the Internet embodies a culture that, too, is not germane to the African environment. High levels of Short Message Service (SMS) usage in Africa have been adversely affected by the prevalence of pre-paid users; however, as the International Telecommunications Union (ITU) (2004) notes, if African users are choosing the pre-paid option because it is less expensive than subscription, they may choose to send SMS if they are cheaper than voice calls. Although these services are just emerging in Africa, they may fare well in the future since such a notable market gap exists in service offerings.

In this context, though, one should note that African states are exceedingly dependent on satellites with more than 95 percent of international traffic carried by satellite in the majority of countries, yet it is increasingly difficult for them to lease capacity on the satellites above Africa for they are heavily subscribed (Commonwealth Telecommunications Organisation, 2002). As the Regional African Satellite Communications Organisation (RASCOM) prepares to launch a satellite to meet some of the needs of the continent, it is faced with the challenge of securing an allocation of orbital space, for ironically, "there are an estimated 300 satellites across the equator that cuts through Africa yet none of them serves the continent" (African Telecommunications Union (ATU), 2001a).

The ATU realizes that to achieve sustainable development and create effective regional economies as well as ensure the fundamental right to communicate, it is imperative that Africans, who do not live in the capital cities, but in rural communities, are provided with telecommunication services; otherwise the existing inequities in the distribution of power and wealth become increasingly entrenched. The ATU recognizes the preponderance of the problems and seeks to redress the rural-urban divide in both Internet and telephony access through forging public-private partnerships in an effort to develop the telecommunications or information communications sector. 


\section{THE CREATION AND STRUCTURE OF THE ATU}

The ATU is a specialized agency or organ of the recently created African Union (AU), which was officially formed in July 2001 to replace the Organization of African Unity (OAU). The ATU is based in Kinshasa, the capital of the Democratic Republic of the Congo, but due to the war there has been temporarily moved to Nairobi, Kenya. The ATU was established with 26 member states as signatories in December 1999 as the successor to the Pan-African Telecommunications Union (PATU). To ensure that the ATU is more than a mere change of names, it employs the instruments of its constitution, convention, and administrative regulations (African Telecommunications Union (ATU), 1999). The ATU was also structurally altered to include a General Secretariat, comprising a secretary general who serves as the chief executive officer, and a management team, composed of the directors of the development and technical sectors. The most notable change, though, is the creation of a new class of membership - the associate member-in an effort to bridge the differences between the public and private sectors in both policies and operations (Gideon, 2000).

In the process of promoting the accessibility and use of information technologies, the ATU also recognizes the need for African states to create strong, though lean, independent regulators. Because many African states have a weak regulatory mechanism and no clear policy or legislation regarding the telecommunications sector, the ATU assists in policy formulation and advises and oversees the financial and technical regulatory plans of its member states. Many governments, in their haste to promulgate telecommunications laws in response to, principally, external pressure, have failed to establish an institutional mechanism to continuously review sector policy (Commonwealth Telecommunications Organisation, 2002). This situation can be remedied as the ATU seeks to design policies and legislation that create a more liberal and competitive telecommunications sector that accommodates, if not mandates, a greater role for the private and non- profit sectors and private-public partnerships. The ATU supports the creation of well-structured public-private partnerships in its member states, because it is thought that such partnerships can provide the resources to build a regional telecommunications infrastructure. In its effort to construct public-private partnerships, membership in the ATU includes government and independent telecommunication regulators as well as public and private service providers.

\section{Associate Members}

Any private entity involved in the information communications sector, which is registered in a country that is a member of the ATU, may apply for associate membership. Entities that are registered in an African country that is not a member of the ATU, which is, generally speaking, a country that is not a member of the AU, are still eligible for membership. The ATU thus has the potential to comprise hundreds of associate members, for such membership embraces a variety of categories, including operators, service providers, ICT vendors, and industrial, scientific, and educational organizations. Operators may be fixed network operators or mobile network operators, cable operators or satellite operators. Service providers may be Internet service providers, application service providers, television broadcasters or radio broadcasters. ICT vendors include companies that may provide, among other services, operational support systems, billing system software, and fixed or mobile network technology. A diverse range of organisations may also apply for associate membership, including consulting agencies, publishers or news media, universities, investment banks, and regional telecommunication organisations, such as the Telecommunications Regulators Association of Southern Africa (African Telecommunications Union (ATU), 2001b).

Through participation in various activities undertaken by the ATU, such as conferences, seminars, workshops, and colloquia, associate members may contribute to the development of policy, regulation, network standards and interconnection rates. Associate members may nomi- 
nate and be nominated as chairpersons of the Technical and Development Conference, but may only attend the Conference of Plenipotentiaries and Council of the Union as observers without voting privileges (African Telecommunications Union (ATU), 2001b).

\section{Organisational structure of the ATU}

The ATU is composed of five principal constituents: the Conference of Plenipotentiaries, the Administrative Council, the Technical and Development Conference, the General Secretariat, and Non-Permanent Units. The Conference of Plenipotentiaries (CPL), the supreme policy organ of the ATU, is attended by Ministers of Communications who meet every 4 years to approve strategic plans and budgets on a 4-year cycle. The CPL also holds authority to revise, as necessary, the ATU constitution and convention, and elect both the secretary general and members of the Administrative Council. The Administrative Council, which meets on an annual basis, is responsible for the implementation of the strategic plans and approves the annual work programmes and budgets and also generates all memoranda of understanding with regional and global partners (African Telecommunications Union (ATU), 2001b). The ATU has signed cooperation agreements with, for example, the Intergovernmental Authority on Development, the Regional African Satellite Communications Organisation, and selected regional economic organisations such as the Common Market for Eastern and Southern Africa. The Technical and Development Conference sets standards and guidelines and essentially serves as the forum for exchange between public and private sector stakeholders on a variety of policy, regulatory, technical and financial issues.

\section{ATU Budget}

Annual contributions from the member states and the associate members, the amount of which is based on the budget adopted by the Council and according to a scale adopted by the CPL, constitute the primary financial basis of the ATU. Contributions for associate members are assessed on the scale of contribution of the member state in which it is registered. There are three contribution levels for associate members: corporate-gold is equivalent to one-quarter of the member state's contribution; corporate-silver is equal to oneeighth and corporate-bronze one-sixteenth of the member state's contribution (African Telecommunications Union (ATU), 2001b). These are minimum contribution levels, determined in part on the size of the company or firm in question, and all members are, of course, encouraged to contribute additional assets to further strengthen the financial base of the ATU (African Telecommunications Union (ATU), 2000). Other financial resources include extra-budgetary contributions and donations approved by the Council, voluntary donations, sundry income from services rendered, and income generated by the Business Unit (African Telecommunications Union (ATU), 1999). When arrears of contributions are paid in excess of the debts that the ATU owes to staff and third parties, the surplus funds will be employed to finance work programme activities (African Telecommunications Union (ATU), 2001b).

One of the primary factors that constrained the PATU's ability to succeed was inadequate financial support from many of its members. The ATU, too, is hampered in its endeavours due to membership arrears. In April 2001, the General Secretariat presented to the Council budgetary estimates for the financial year 2001-2002 in the amount of US\$833,635, holding to the ceiling of the previous year (African Telecommunications Union (ATU), 2001c). The limited number of ATU staff and the trend of low membership contribution necessitated this prudent approach to financial management. Although the Council approved the budget, it also recommended that the secretary general appeal to those member states that owe the ATU a considerable amount of arrears of contribution. While external donors could assist in nurturing the development of the ATU, such support could not be provided indefinitely and dependence on foreign aid, which Nkrumah (1963) describes as one of the more subtle forms of neo-colonialism, is best avoided. 
Thus it is imperative that African states be financially forthcoming.

\section{STRUCTURAL WEAKNESS OF THE ATU}

Although membership fees are small in comparison to what most states spend on their own security or military apparatus, financial constraints seriously hamper the efforts of the ATU because governments fail to pay the arrears on their dues. Since key administrative appointments are often highly politicised, governments are generally more willing to pay their fees to regional or continental associations when the secretary general and other top staff are from their state or the institution is headquartered in their country (Daddieh, 1995). Unfortunately, the ATU is financially dependent on governments for it remains essentially an inter-governmental organisation. As of August 2002 the ATU consisted of merely 10 associate members. 1 The ATU needs to provide clear incentives for its existing members to pay their fees as well as conduct extensive outreach to build a base of private participants or its demise is certain.

Like other Pan-African approaches, the fundamental issue that must be addressed concerns representation. Having nation-states as members of the ATU with full voting privileges constitutes a top-down approach to telecommunications development. Although the World Telecommunications Advisory Council recommends that the telecommunications sector be raised to the highest political level, the general public too needs to be informed of the issues and the ramifications of decisions to stimulate policy discussion and make politicians more responsive to their needs (Jensen, 1995). The ATU cannot claim to represent users for they have no voice and no vote in non-democratic and politically unstable states, which continue to dominate Africa. Thus, despite the ATU's attempts to create a transparent, participatory structure that is accountable to its members, it is difficult to see how the ATU can be an enduring democratic institution if its constituent member countries lack good governance and strong constitutional rights for its citizenry.
As Mbaku (1999) writes, each new set of political elites, whether they are civilian or military, suspend or discard existing constitutions and draft new ones to legitimise their rule. These same African rulers zealously defend their sovereignty and lack the political will and commitment to subordinate domestic political and economic interests to supranational institutions with long-term regional integration goals (IbeikeJonah, 2001). They often fail to support regionalism and South-South cooperation because they are politically and economically aligned with leaders of the G-8 as they seek to reap the riches of their countries and their international linkages for personal profit (Brown, 1996). Daddieh (1995) suggests that the absence of sound political leadership, coupled with the failure to organize, nurture and involve the civil society in the articulation and implementation of regional policies, has resulted in ineffectual integration efforts. To integrate, African states must essentially be deconstructed and the state apparatus reconstructed to increase popular participation and reduce political opportunism. According to Davidson (1994), what is needed is a decolonisation of institutions.

\section{THE POST-COLONIAL AFRICAN STATE}

The colonial state, in its design as an authoritarian, exploitative, and repressive structure, failed to address issues of public accountability, political representation, and constitutionally guaranteed civil rights and civil liberties, which meant that these attributes of government were not transferred to the local political elites. The postcolonial state is thus not generally representative of the majority of its citizens. The colonial state with its absence of democratic principals and customs became the superstructure upon which African political elites constructed a mercenary or predatory state, characterised by economic mismanagement, social injustice, political instability, and corruption coupled with personal and ethnic loyalties. This situation grew further entrenched by African countries' colonial inheritance of the centrist function of the state in the development of the economy (Iheduru, 2001). 
Upon independence many African governments undertook large-scale development projects, including management of the telephone companies, for which local entrepreneurs, like the governments, had insufficient expertise and resources. Governments financed and managed these projects by borrowing heavily from the World Bank and International Monetary Fund. According to Iheduru (2001), not only were the governments incapable of successfully embarking upon such a wide range of activities, the large capital transfers enabled the local political elites to pillage the state treasury while providing a façade of national development. The resultant economic mismanagement and waste, and the consequential financial and political crisis, which spanned the continent by the late 1970s, engendered the restructuring of the national economies (Iheduru, 2001).

By the mid-1980s most African states were engaged in externally designed structural adjustment programmes because the Bretton Woods institutions and other bilateral development aid agencies required economic restructuring as a lending conditionality. By emphasising the market allocation of resources, the role of the state was to be reduced. The argument advanced was that economic structural adjustment, despite its short-term negative social consequences, would generate the impetus, internally and externally, to deconstruct the post-colonial state and its reconfiguration would serve as an initial step toward eventual economic growth in the country (Iheduru, 2001). This approach has proven largely unsuccessful, principally because in the process of adjustment governments are to adopt policies that may be economically rational, but are irrefutably politically irrational as the state is to dismantle its own power through employing institutional and public sector reforms, which may entail divestment, curtailed subsidies for stateowned enterprises, reduced protectionism and trade liberalization. This orthodox paradox also presents a quandary for integrative organizations, as they too require states to curtail their power in favour of a regional institution.

\section{THEORIES OF INTEGRATION}

There are basically two contrasting approaches to integration, the functionalist and the neofunctionalist. Theorists of both views contend that states, which share interests, values, objectives, and experiences, need to concede their sovereignty to realize mutual goals. The functionalist approach views integration as an evolutionary process, in which states initially cooperate on specific, apolitical projects and in so doing learn to trust one another to the point where a political union can evolve. The neo-functionalists are principally concerned with the rate of integration and the creation of structural mechanisms to resolve inevitable disputes and divergence of views. The neo-functionalists contend that the slow pace of the evolutionary approach allows for more time for differences to develop and fester, which would create an impasse in the process toward integration, notably because the functionalists lack the mechanisms to address the numerous complications inherent in moving from nonpolitical areas of cooperation to political union. The neo-functionalists thus favour the creation of institutional instruments to respond to political and other differences as they arise and to penalize errant members (Akpuru-Aja, 2001).

\section{THE OAU/AU}

Since the formation of the OAU in 1963, numerous inter-governmental institutions aimed at integration have been formed, but they are each only as strong as their member states empower them to be. As African leaders jealously guard their state sovereignty, they fail to charge the integrative organizations with the powers, legal and resource-wise, to enforce regional policies at the national level. This serious problem is rooted in the structure of the OAU, which missed an important, initial opportunity to form a political federation of African states. The Charter of the OAU was itself contradictory or hypocritical in that its signatories pledged to defend the sovereignty, independence, and territorial integrity of Africa's states while simultaneously getting rid of all forms of colonialism in Africa, though the artifice of the nation-state was its most insidious relic. Although the charter of the AU, which was 
officially formed in July of 2001 to replace the OAU, maintains the colonially defined nationstates, it differs from its predecessor in that it includes "respect for democratic principles, human rights, the rule of law and good governance," but the transference of these words into practice is what is at issue (Ibeike-Jonah, 2001). Simply signing an agreement achieves naught, as a review of treaties, conference resolutions and protocols agreed to by African states reveals that they have rarely been translated into actions and commitments (Akpuru-Aja, 2001). It is imperative, though, given that the telecommunications network is a fundamental infrastructure with a pervasive effect on the performance and development of an economy, that the ATU not befall the same fate as other regional initiatives and become another ineffectual Pan-African organization.

\section{CHANGING THE ROLE OF REGIONAL ECONOMIC ORGANISATIONS}

For the ATU to be an effective, integrative association, a high degree of uniformity in telecommunications policy among African regional organizations as well as individual member states is of critical importance. There are several major regional economic associations in Africa, including the Economic Community of West Africa (ECOWAS), the Common Market for Eastern and Southern Africa (COMESA), the Economic Community of Central African States (ECCAS), the Southern African Development Community (SADC), the East African Community (EAC), the Community of Sahel and Saharan States (CED-SAD), and the West African Economic Community (CEAO), which comprises francophone countries. In an attempt to ensure a uniformed approach to telecommunications development, regional economic organisations and their corresponding telecommunications units should be considered, not as associate members, but as members of the ATU with all the privileges thereof and thereby replace the individual nation-states as representatives. This structural alteration would represent a revolutionary ap- proach to a continental organisation and advance the efforts of the AU toward integration.

The existing configuration of these regional economic organisations, however, requires restructuring, because they do not conform to the AU's division of the continent and there is overlap among the members. Several states in Southern Africa, for example, are members of both COMESA and SADC. The economic costs of participation in two regional organisations and the potential for incongruent policies must be avoided. The AU has divided the continent into five sub-regions: (1) North Africa, comprising six states, Algeria, Egypt, Libya, Mauritania, Morocco, and Tunisia; (2) West Africa, comprising 14 states, Benin, Burkina Faso, Cote d'Ivoire, Gambia, Ghana, Guinea, Guinea Bissau, Liberia, Mali, Niger, Nigeria, Senegal, Sierra Leone, and Togo; (3) Central Africa, comprising 10 states, Angola, Burundi, Cameroon, Central African Republic, Chad, Congo, Democratic Republic of the Congo, Equatorial Guinea, Gabon, and Sao Tome and Principe; (4) East Africa, comprising 10 states, Comoros, Djibouti, Ethiopia, Kenya, Madagascar, Mauritius, Somalia, Sudan, Tanzania, and Uganda, and (5) Southern Africa, comprised of six states, Lesotho, Malawi, Republic of South Africa, Swaziland, Zambia, and Zimbabwe (African Telecommunications Union (ATU), 2002). Five major regional economic organisations, based on the AU's design, could thus replace the existing associations and avoid duplicate membership.

In order for this strategy to succeed, though, the potential for incongruent policies between these groupings must be addressed and the problem of political leadership, as noted earlier, must be remedied through good governance and strong constitutional rights. Also, regional integration organisations and stratagems must be incorporated into the educational system or curriculum, beginning at the elementary school level. The media, too, must focus greater attention on integration efforts to ensure that the people understand what such schemes are intended to achieve. An educated public must then be organized into private regional advocacy associations to ensure that regional commitments and goals are not 
subordinated to national ones (Daddieh, 1995). Such strategies to promote regional integration have not, however, been enlisted to date (Ihonvbere, 1999). Leaders must come to realize, though, that African states will be further marginalized if they do not pursue collective selfreliance and political and economic regional integration, the long-term benefits of which will surpass any immediate costs.

\section{REGIONAL EFFORTS AND INTEGRA- TION IN TELECOMMUNICATIONS}

Success in macro-level regional schemes have been elusive, largely because of the lack of confidence and trust at the interstate level, which reflects internal dilemmas within African states as the citizens distrust their national governments (Akpuru-Aja, 2001). Since cooperation on issuespecific areas, such as telecommunications, may offer better potential for success, these microlevel measures can assist in constructing confidence in regional organisations. In turn, they can become the building blocks for achieving macrolevel regional integration, which is necessary to promote socio-economic development goals and overcome the balkanisation of the continent during the colonial era. The small size of the telecommunications market caused by low levels of economic development, coupled with perceived high investment risks and uncertain regulatory environments, necessitates that actions in regard to this sector be pursued within the framework of comprehensive sub-regional plans. An individual country's attempts at improving the telecommunications sector will be futile if neighbouring states are not exerting similar efforts (Matsebula \& Simelane, 1996).

African regional organisations, in recognising the important role telecommunications plays in development, need to require member states to lower, if not eliminate, import tariffs on information technology hardware such as computer equipment and printers. Communications equipment is often treated as a luxury item and thus heavily taxed, because many African states use these tariffs as a source of revenue (Oshikoya \& Hussain, 1999). Telecommunications initiatives will only succeed if African governments realize that lowering import tariffs will actually serve as a greater stimulus for development than as a means of revenue generation (Jensen, 1995).

In addition to tariff reductions, equipment and services need to be coordinated as regional or group purchases, because costs can be substantially cut through bulk purchasing. Indeed, as Jensen (1995)notes, if a sufficient number of countries can agree on a joint procurement policy, not only can greater volume discounts be negotiated with suppliers, the operators can benefit from sharing the skills developed in operating the same equipment. Shared technical standards, too, can be developed which will further facilitate regional integration. Jensen (1995) suggests that it may even be beneficial to establish regional telecommunications operators, which could achieve sufficient economies of scale to support research and development investments and provide one-stop, uniform availability of international and national network services. To date, however, neither the ATU nor any of the regional economic organizations are engaged in regional procurement of equipment or the creation of regional operators, though some have created regional regulatory associations.

\section{Regional regulatory associations}

The SADC provides a model for the establishment of a regional regulatory organization. In an effort to bridge the gap between the formulation of regional legislation and policies and effective execution at the national level, SADC created the Telecommunications Regulators Association of Southern Africa (TRASA), the Constitution of which became effective on 22 April 1998. Relevant SADC structures also endorsed regional telecommunications policies and a Model Telecommunications Bill as a guideline in formulating national legislation (SADCC-TU, 1999). The restructuring of the incumbent national operator, specifically the termination of its ability to prescribe the tariffs at which it provides telecommunications services and its powers to make bylaws and regulation, as well as the establishment of an independent regulatory authority and its 
duties and powers are the twin foci of the Bill. As the formerly self-regulating fixed line monopoly service providers lose their regulatory powers with the creation of independent regulatory agencies, the creation of TRASA was considered essential to facilitate regional telecommunications reform and enhance service provision.

Membership in TRASA is moreover contingent upon a country's law providing for the establishment of an autonomous regulatory authority. Countries, which do not possess independent regulators, can participate in the activities of TRASA, but do not have voting rights (Southern Africa Transport and Communications Commission (SATCC) (1999a) and Southern Africa Transport and Communications Commission Technical Unit (SATCC) (1999b)). Members share the cost of operating TRASA equally (Telecommunications Regulators Association of Southern Africa (TRASA), 1997). According to Article 3 of the TRASA Constitution, the objectives of the organization are to "co-ordinate regulatory matters and ... promote the establishment and operation of efficient, adequate, and costeffective telecommunications networks and services in the Southern Africa region which meet the diverse needs of customers while being economically sustainable" (Telecommunications Regulators Association of Southern Africa (TRASA), 1997).

These goals, to varying degrees, are also shared by other regional regulatory associations, including the West Africa Telecommunication Regulators Association (WATRA), which was formally inaugurated in May 2002 and has since established its secretariat at the Economic Community of West African States secretariat in Abuja, Nigeria and the Association of Regulation of Information and Communications of Eastern and Southern Africa (ARICEA), which was launched in January 2003 as the regulatory association for the Common Market for Eastern and Southern Africa. COMESA also seeks to facilitate increased trade relations among its member states by supporting the creation of a regional telecommunications network that is to be built and managed by the private company COMTEL
Communications Ltd (African Telecommunications Union (ATU), 2003). Both ARICEA and WATRA encourage the separation of the roles of policy-maker, regulator, and service provider, but membership in these organizations, unlike TRASA, is not subject to the creation of an independent regulator. Rather Article 3 of the WATRA Constitution states as one of its objectives, "the establishment of distinct, independent and adequately empowered national telecommunications regulatory agencies in countries in the sub-regional where such agencies have not been created" (West Africa Telecommunications Regulators' Association (WATRA), 2002, p. 5). Membership in WATRA and ARICEA is thus open to the regulators of all countries in the respective sub-regions, be they independent institutions or integrated with the state-owned service provider, provided that one regulator represents each country. Not only do both of these regional regulatory associations lack criteria for membership, they, like TRASA, also lack any power of enforcement.

In pursuance of its objectives, Article 3.2(a) of the WATRA Constitution and Article 3.2(b) of the ARICEA Constitution state that the regulatory association may "deliberate on issues" relating to telecommunications regulation and the development and application of information and communication technologies and "make recommendations" to the respective governments of member states or other relevant or appropriate authorities (Common Market for Eastern and Southern Africa (COMESA), 2003; West Africa Telecommunications Regulators' Association (WATRA), 2002). The Constitutions fail, however, to render member states accountable for adopting these recommendations. Although Article 16 of the ARICEA Constitution and Article 10.7 of the WATRA Constitution state that sanctions may be imposed against any member that is in arrears of its annual dues for more than 1 year for reasons other than exceptional circumstances, this is an insufficient disciplinary measure, which is only employed in cases of financial default. No mechanisms have been instituted to penalise a state for its failure to adopt recommendations, which further policy harmonization in regard to 
the restructuring of the telecommunications sector. These regional regulatory associations are thus essentially impotent, as they have yet to be entrusted with the means of enforcement.

Although a deficient telecommunications system can be considered the foremost non-tariff barrier to intra- and extra-African trade, the World Bank contends that large infrastructure investments will not stimulate regional integration unless various other regulatory, procedural and administrative obstacles that obstruct trade are first removed (Daddieh, 1995). Structural adjustment programmes, intended to remove these barriers, have, however, yet to be designed to incorporate regional reform strategies and explore ways in which responsibility for regional disbursement of loans can be shared (Daddieh, 1995). Adjustment programmes themselves have served to reinforce the arbitrary, colonially defined nation-states, without recognising or supporting regional integration structures. The World Bank and the International Monetary Fund continue to treat individual African states in isolation and have not begun to strengthen regional cooperation efforts (Brown, 1996). Nonetheless, for African states to coordinate and streamline their economies, undertake adjustment as a single unit, and directly confront the problem of persistent structural economic dependence, economic decisions taken nationally will have to take into account regional positions and circumstances. African leaders need to accept that some decisions, previously made at the individual national level, will be taken collectively through regional institutions and will be binding on all. If the international financial institutions possessed this understanding, the East African Community (EAC) Digital Transmission Project would not have been aborted.

\section{EAC-digital transmission project}

To create a single market and investment area, the East African Community, comprising of Kenya, Uganda, and Tanzania, sought to interconnect the three countries with international submarine cable networks. The proposed US\$60 $\mathrm{M}$ project, overseen by a steering committee composed of the CEOs of the three telephone companies, Telkom Kenya, Tanzania Telkom, and Uganda Telkom, aimed at introducing state of the art technology to accommodate the growing demand for telecommunications services in the region (African Telecommunications Union (ATU), 2000). According to Mureithi (1999), the European Investment Bank (EIB) committed to extend loan facilities for 50 percent of the total project costs and intended to cover all foreign exchange component costs. The loan package was part of risk capital to be taken over directly by the project overseers, that is, the telephone companies of each country, without the respective governments' guarantees. To further assure success of the project, the companies urged the three governments to extend support by waiving duties and taxes, which both Uganda and Kenya agreed to do. The East African Development Bank was also to provide a loan. The World Bank, however, effectively blocked the EACDigital Transmission Project by not allowing Tanzania to commit to additional loans in the telecommunications sector beyond US\$2 M. The Bank held Tanzania to the terms of the US\$250 M Telecommunications Restructuring Programme, which it signed in 1993 (Mureithi, 1999). This stance on behalf of the World Bank in refusing to refuse to consent to Tanzania's request to secure additional funds for the telecommunications sector not only demonstrates the rigidity and inflexibility of the World Bank, but also its utter disregard for viable indigenous projects to facilitate regional integration.

Regional monetary and financial institutions must be strengthened, as Amin (1997) suggests, so that they may serve as substitutes for the IMF and World Bank for securing capital. Such initiatives are difficult to launch, though, as Japan can testify, for in 1997 it offered $\$ 100$ billion to help create an Asian Monetary Fund in order to finance the required action to alleviate the financial crisis afflicting East Asia, but was thwarted in its efforts by both the IMF and the US Treasury (Stiglitz, 2002). As the only shareholder with veto power in the IMF, the US maintains considerable leverage over IMF policies. It would be unlikely to retain such a position in an Asian 
Monetary Fund in which Japan, and possibly China, would be the likely major contributors and hence whose voices would predominate (Stiglitz, 2002). The countries of East Asia did, however, later quietly create a more modest version of the proposed Asian Monetary Fund under the innocuous name of the Chang Mai Initiative (Stiglitz, 2002).

Amin (1997) argues that regional economic integration requires corresponding political integration and the rapprochement of national policies. Since no economy exists without politics and a state, economic globalisation logically requires the construction of a world political system of which regional entities are necessary transitional steps (Amin, 1997). The ATU thus assumes increased importance in this present era, which is characterised by a separation between the globalised space of capitalism's economic management and the national, and regional, spaces of its political and social management (Amin, 1997). While maintaining a degree of flexibility so as to allow member states to proceed at different paces, the ATU, like the existing regional organisations, must, however, be invested with sufficient powers of enforcement to discipline delinquent members and achieve its objectives.

\section{GOALS OF THE ATU}

The ATU has articulated numerous objectives, as it seeks to:

a) promote the development and adoption of appropriate African telecommunications policy and regulatory frameworks;

b) promote the financing and funding of telecommunications development;

c) promote programmes for the development of the African Information Society;

d) prepare special programmes for Africa's Least Developed Countries (LDCs) and rural telecommunications development;

e) promote human resources development in the field of info-communications; f) promote the establishment of infocommunications industries;

g) co-ordinate the strategies and positions of Member States in preparation for and at international meetings;

h) promote regional coordination in areas of value-added services, equipment certification, technical standards and harmonisation of tariffs;

i) seek to harmonize the actions of Member States and Associate Members in the telecommunications sector;

j) foster co-operation and partnership between and among Member States and Associate Members;

k) promote and encourage the exchange of information, expertise and technology relating to info-communications for the benefit of all Member States and Associate Members;

1) undertake studies in the field of infocommunications for the benefit of Member States and Associate Members; and

m) undertake all such activities not defined above which may assist in achieving the mission and vision of the Union (African Telecommunications Union (ATU), 2001b).

These objectives, while laudable, are too broad in scope. Clearly defined goals or benchmarks and specific strategies to achieve them will make the organisation not only more effective, but also the benefits of membership more saleable. Achievements, too, can then be readily measured and it becomes easier to prioritise the areas that are still in need of improvement. The ATU needs to coordinate regional procurement of equipment, institute a continental universal service fund, and set targets for pay phone distribution as well as other creative strategies to facilitate telephone access, such as tele-centers. In the absence of concrete, tangible objectives, the ATU will remain essentially ineffectual and merely a forum for proposing policies and standards. Its strategic plan, known as the African Connection, too, is written in general terms. 


\section{THE AFRICAN CONNECTION}

In August 1998 at the CPL held in Lusaka, Zambia, the 44 member-states of the PATU, in approving resolution $07 / 6 \mathrm{~S}-\mathrm{CPL} / 98$, adopted the African Connection as its strategic plan for 1998-2002. The annex to this resolution concerns the ministerial oversight committee, which is open to all member states, and has a core group of 11 countries structured in accord with the AU's five-region division of the continent. Current members of this committee, which represent the ATU Plenipotentiary and an African Connection Project Trust and Secretariat, include Egypt and Libya for North Africa; Cameroon and the Democratic Republic of the Congo for Central Africa; Sudan and Uganda for East Africa; Gambia, Ghana, and Niger for West Africa; and Zimbabwe and the Republic of South Africa for Southern Africa (African Telecommunications Union (ATU), 1998). The Republic of South Africa, which has largely spearheaded the initiative, serves as the chair of the ministerial oversight committee.

While the African Connection, whose program is being developed under the auspices of the ATU, does not outline a representative role for the regional economic organisations and persists in employing the nation-state as the unit of representation, it does recognise that African policy-makers and businessmen need to go beyond individual country programmes and create regional telecommunications markets. A Secretariat for the African Connection was established to create the requisite institutional support for managing cross-country linkages and coordination, since the African Connection seeks to serve as a clearinghouse of information and first point of contact for regional regulatory framework development. The African Connection also seeks to coordinate regional donor assistance and in so doing promote economies of scale on subregional and regional levels (The African Connection, 1999). The high level of African leadership and support for the African Connection is noteworthy as is the positive response from bilateral and multilateral lending institutions. The language of the document, however, as noted, is sufficiently vague in many respects to be effective.

This is exemplified in the first chapter of the African Connection, entitled Special Programme for Least Developed Countries and Rural Telecommunications Development, which states that the "promotion of universal access should be the driving [author's emphasis] force of change, while at the same time creating entrepreneurial opportunities at a local level" (African Telecommunications Union (ATU), 1998). The document seemingly contradicts itself, however, when stating that "[s]trategies that loop some LDCs and other countries into regional markets to ensure a critical mass that will interest investors to finance viable projects that guarantee a commercial return on investment while having some [author's emphasis] universal service or access obligations, need to be looked into" (African Telecommunications Union (ATU), 1998). At no point, though, does the African Connection define universal access or propose how it should be achieved. Defining universal service policy objectives is, however, an integral part of the legislative development process, for it empowers regulators to establish and enforce the mechanisms for implementation of the policy. Without such definitions and guidelines, it is not possible to make any assessments of progress on a national or regional level. The African Connection also fails to provide critical information in regard to other areas.

Regarding human resources, the inadequate funding and development of which is endemic to African institutions and undermines all institutional endeavours, the third chapter of the African Connection contends that creating a network of human resources at the national, regional and continental level is essential. To facilitate such networking and promote an information technology culture, it recommends increased electronic meetings or communications between different government departments within the same country as well as constant periodic electronic communication between governments of different countries (African Telecommunications Union (ATU), 1998). While this could assist in ensuring that knowledge and experience as well as perhaps 
funding is shared, many government departments do not have access to the Internet or electronic mail. The African Connection does not specify how this initial impediment is to be remedied.

In describing proposed projects in the areas of tele-medicine, tele-education and teleagriculture, the African Connection does not address the fundamental question of resource allocation, for the use of new communication technologies consumes funds that may be deemed more necessary elsewhere. For example, while some health care workers extol the satellite systems and computer networks that have brought them access to medical information, others denounce the proclaimed advantages of telemedicine because no new knowledge about typical diseases which afflict Africa, such as diarrhea, tuberculosis, and cholera, can be derived from the consultation of medical databases (Afemann, 1997). Most diseases in Africa are a result of malnutrition, inadequate housing, and generally poor, unsanitary living conditions. Not only can the Internet not solve these problems, it cannot provide desperately needed antibiotics, vaccines and syringes. It is essential to be ever mindful of the fact that the provision of information, while useful, even crucial, for many rural poor people is inadequate, the conditions and resources for the implementation of such information into practice must also be provided. The African Connection does not address this vital point, nor, as noted, does it set specific benchmarks and detail strategies to achieve them, thus the African Connection is insufficient as a strategic plan for the ATU. The lack of sufficient details to implement an effective ICT programme also afflicts another recent African initiative, the New Partnership for Africa's Development or NEPAD.

\section{NEPAD}

Formed in 2001, NEPAD proposes four programmes as priorities to be addressed in the quest for development, including communicable diseases, specifically HIV/AIDS, malaria and tuberculosis; debt reduction; market access; and information and communication technology (ICT). In the ICT sector the NEPAD Task Team is known as the e-Africa Commission, which serves as the primary advisory body to the Heads of State and Government Implementation Committee of NEPAD on the development of an effective and comprehensive ICT programme in Africa. The NEPAD document, "The Strategy for Achieving Sustainable Development in the 21st Century," in recognising that Africa's poor ICT infrastructure constitutes a serious handicap to economic growth and poverty reduction, outlines five objectives with respect to information and communications technology:

- to double teledensity to two lines per 100 people by 2005 , with an adequate level of access for households;

- to lower the cost of and improve reliability of service;

- to achieve e-readiness for all countries in Africa;

- to develop and produce a pool of ICTproficient youth and students, from which Africa can draw trainee ICT engineers, programmers and software developers;

- to develop local content software, based especially on Africa's cultural legacy (A New African Initiative, 2001).

While these goals are commendable, the NEPAD document, like the Africa Connection, fails to articulate how these aspirations are to be realised. The NEPAD document stipulates five actions to be taken in regard to telecommunications:

- work with regional agencies such as the ATU and Africa Connection to design model policy and legislation for telecommunications reform, and protocols and templates for ereadiness assessments;

- work with the regional agencies to build regulatory capacity;

- establish a network of training and research institutions to build high-level man-power; 
- promote and accelerate existing projects to connect schools and youth centres;

- work with development finance institutions in Africa, multilateral initiatives (G-8 DotForce, UN Task Force) and bilateral donors to establish financial mechanisms to mitigate and reduce sector risks legacy (A New African Initiative, 2001).

Not only is the level of generality at which these actions are stated problematic, there are other regional and continental agencies in Africa, such as the ATU, devoted to ICT development and the harmonization of policies in regard to the telecommunications sector. Such redundancy of effort on behalf of NEPAD is thus unproductive. To redress the widening digital chasm Africa faces, neither requires duplication nor overlap of action, but a decisive response on behalf on African leaders to upgrade and expand the telecommunications sector in a coordinated manner at the regional level.

\section{CONCLUSIONS}

The welfare of the people of Africa and the development of an integrated regional economy requires the empowerment of regional organisations to achieve concerted and higher levels of coordinated regional institutions and actions. In the process of promoting intra-regional trade and supporting industrial development and growth, the upgrading and development of the telecommunications sector must remain a priority if Africa is to redress its marginalization in an increasingly integrated global economy. Given the disparate size and level of development of individual African states, there is a clear need for a comprehensive and coordinated telecommunications policy at a regional and continental level to create markets which take advantage of economies of scale. Small market size in conjunction with perceived high country risks creates an environment adverse to investment in African states. A continental approach, as proposed by the ATU, has been identified and agreed to in various fora on the continent, principally because isolated country policy and regulatory reform has proven insufficient to advance the continent technologically. In harmonising a continental or 'African' voice at global conferences, such as the ITU, the ATU can champion critical issues facing African states, such as in regard to spectrum allocation.

The ATU, however, must address and resolve a wide variety of complex issues. In addition to market size and structure, the current diversity and inconsistency of regulatory regimes and the inability and high cost of securing information on the legal and regulatory frameworks in each country adversely affects investor confidence. The ATU is thus obliged to create a continental regulatory association, comprising the regional regulatory associations, to ensure uniform, wellbalanced and transparent regulatory structures. Clearly defined benchmarks must also be agreed upon and the strategies to achieve them implemented. The ATU needs to build its base of private participants and restructure its institutional framework to ensure more equitable distribution of costs and benefits among members. To promote regional telecommunications initiatives as well as advance the efforts of the AU toward integration, the ATU also needs to replace the individual nation states as members of the ATU with regional economic organisations. For as Nkrumah (1963) wrote, "just as our strength lies in a unified policy and action for progress and development, so the strength of the imperialists lies in our disunity."

\section{ACKNOWLEDGEMENTS}

The author would like to thank Howard University for the Social Sciences, Humanities, and Education Grant which facilitated this research.

\section{REFERENCES}

A New African Initiative Merger of the Millennium Partnership for the African Recovery Programme (MAP) and OMEGA Plan. (July 2001). Pretoria, South Africa: NEPAD. 
Afemann, U. (1997). Internet for the third world - chance or threat? Available: http://www.uni-

muenster.de/EthnologieHeute/eh1/afe.htm. [2001, 3 February].

African Connection. (1999). The African Connection. Available: http://www .africanconnection.org//about.cfm. [2001, 16 November].

African Telecommunications Union (ATU). (1998). ATU strategic plan 1998-2002 the African Connection building Africa's communications infrastructure. Lusaka, Zambia, August.

African Telecommunications Union (ATU). (1999).Constitution and convention of the African Telecommunications Union. Cape Town, South Africa, December.

African Telecommunications Union (ATU). (2000). ATU Newsletter. Nairobi, Kenya, December.

African Telecommunications Union (ATU). (2001a). ATU Newsletter. Nairobi, Kenya, August-December.

African Telecommunications Union (ATU). (2001b).Associate membership information pack. Nairobi, Kenya, August.

African Telecommunications Union (ATU). (2001c). Final report of the 2 nd ordinary session of the administrative council, 23-27 April. Nairobi, Kenya.

African Telecommunications Union (ATU). (2002). African telecommunications union in brief. Nairobi, Kenya.

African Telecommunications Union (ATU). (2003). Pro-

jects. COMTEL. Available: http://www .atu-

uat.org/projects .asp [2001, 4 March].

Akinyemi, N.B. West African regionalism revisited: Cooperative management of the Senegal and Gambia water resources. In O.M. Iheduru (Ed.), Contending issues in African development advances, challenges, and the future, Greenwood Press, Westport, CT (2001), pp. 261-275

Akpuru-Aja, A. The politics of regional integration and development in Africa: Issues, limitations, and prospects. In O.M. Iheduru (Ed.), Contending issues in African development: Advances, challenges, and the future, Greenwood Press, Westport, CT (2001), pp. 277-292

Amin, S. Capitalism in the age of globalization. The management of contemporary society. Zed Books, London (1997)
Brown, M. Africa's choices after thirty years of the World Bank. Westview Press, Inc, Boulder, CO (1996)

Castells, M. The information age: Economy, society and culture. Vol. III End of millennium (2nd ed)Blackwell Publishers, Oxford, UK (2000)

Chango, M. (2004). Africa's information society hindered by culture of secrecy. PanosFeatures. Available: http://www .panos.org.uk/newsfeatures/featuredetails .asp?i d=1206 [2004, 10 August].

Common Market for Eastern and Southern Africa (COMESA). Constitution of the Association of Regulators for Information and Communication Services of Eastern and Southern Africa (ARICEA). COMESA, Addis Ababa, Ethiopia (2003)

Commonwealth Telecommunications Organisation. (2002, September 9). Regional Roundup: AITEC Releases African Infrastructure \& Services Report. ICT Development Agenda. Available:

http://www .ictdevagenda.org/frame.php?dir=07\&sd=10\&si $\mathrm{d}=2 \& \mathrm{id}=252[2002$, October 3].

Daddieh, C. Structural adjustment programmes and regional integration: compatible or mutually exclusive? In K. Mengistreab, B.I. Logan (Eds.), Beyond economic liberalization in Africa structural adjustment and the alternatives, Zed Books Ltd, London (1995), pp. 243-272

Davidson, B. Modern Africa a social and political history (3rd ed). Longman Group Limited, London (1994)

Gideon, F. (2000, April 6). African telecom union takes on new challenges. IDG News Service Southern Africa Bureau. Available:

http://www .idg.net/ec?external=1\&content.source.id=200 \&remote_addr $=\& d o c \_i d=163720 \&$ siteid [2002, January 12].

Ibeike-Jonah, I. Transforming the OAU to African Union. Africa Notes. Institute for African Development, Cornell University (2001)

Iheduru, O. Redefining the African state: Political capacity in the post reform era. In O. Iheduru (Ed.), Contending issues in African development: Advances, challenges, and the future, Greenwood, Westport, CT (2001), pp. 295-314

Ihonvbere, J.O. Regionalism and the politics of collective development in Africa. In J.M. Mbaku (Ed.), Preparing Africa for the twenty-first century strategies for peaceful coexistence and sustainable development, Ashgate Publishing Ltd, Aldershot, England (1999), pp. 199-223 
International Telecommunications Union (ITU). African telecommunication indicators 2004. ITU, Geneva (2004)

Jensen, M. (1995). Telematics for development. Discussion paper presented at the African regional symposium on telematics for development. 3-7 April. United Nations Economic Commission for Africa Headquarters, Addis Ababa. Availa-

ble:http://www.sas.upenn.edu/African_Studies/Padis/telem atics_Jensen.html. [2001, November 1].

Matsebula, M., \& Simelane, V. Small countries within regional integration. In G. Maasdorp (Ed.), Can south and southern Africa become globally competitive economies?, Macmillan Press Ltd, London (1996), pp. 53-60

Mbaku, J. Making the state relevant to African societies. In J.M. Mbaku (Ed.), Preparing Africa for the twenty-first century strategies for peaceful coexistence and sustainable development, Ashgate Publishing Ltd, Aldershot, England (1999), pp. 299-333

Mureithi, M. (1999). East African digital transmission project: Donor power derails project, Summit Strategies, Nairobi, Kenya, 27 June.

Nkrumah, K. Africa must unite. International Publishers Co., Inc, New York (1963)

Oshikoya, T. W., \& Hussain, M. N. (1999). Information technology and the challenge of economic development in Africa. African Development Bank--Economic Research Paper No. 36. Available: www .atdb.org/news/publications/erp36.html. [1999, June 21].

Shanmugavelan, M., \& Warnock, K. Completing the revolution the challenge of rural telephony in Africa. The Panos Institute, London (2004)

Southern Africa Transport and Communications Commission (SATCC). Report on TRASA action programme and implementation issues. Agenda Item No. 6.1. Telecommunications Committee Meeting, Dar es Salaam, Tanzania. SATCC, Maputo, Mozambique (July 1999)

Southern Africa Transport and Communications Commission Technical Unit (SATCC). SADC telecommunication policies \& model telecommunication bill. SATCC-TU, Maputo, Mozambique (May 1999)

Stiglitz, J. Globalization and its discontents. W.W. Norton and Company, New York (2002)
Telecommunications Regulators Association of Southern Africa (TRASA). Constitution of the telecommunications regulators association of southern Africa. TRASA, South Africa (1997)

West Africa Telecommunications Regulators' Association (WATRA). Constitution of the West Africa Telecommunications Regulators' Association. WATRA, Lagos, Nigeria (2002) 